\title{
Morphological Characterization of Lithognathus mormyrus (Linnaeus, 1758) Populations in the Southern Black Sea (Turkey)
}

\author{
Uğur Karadurmuş ${ }^{1}$ (D), Mehmet Aydın² (i)
}

Cite this article as: Karadurmus, U., \& Aydin, M. Morphological characterization of Lithognathus mormyrus (Linnaeus, 1758) populations in the southern Black Sea (Turkey). Aquatic Sciences and Engineering, 37(1), 38-45.

ORCID IDs of the author:

U.K. 0000-0002-5827-0404:

M.A. $0000-0003-1163-6461$

1Bandırma Onyedi Eylül University, Maritime Vocational School, Bandirma, Balıkesir, Turkey

2Ordu University, Fatsa Faculty of Marine Sciences, Fatsa, Ordu, Turkey

\section{Submitted:}

16.05.2021

Revision Requested:

10.07.2021

Last Revision Received:

02.08.2021

Accepted:

20.08 .2021

Online Published:

31.12.2021

Correspondence:

Uğur Karadurmuş

E-mail:

ukaradurmus@bandirma.edu.tr

\begin{abstract}
Morphological characteristics such as meristic counts and body shape have long been used in stock identification. Fifty striped seabream, Lithognathus mormyrus, individuals were sampled from the south Black Sea between January 2020 and November 2020. Morphometric characteristics were given as the percentage of total length (TL\%). Species identification and shape differences between sexes of striped seabream were analyzed by different statistical methods. The biggest maximum length and weight values $(T L=310 \mathrm{~mm}$ for $T W=399.73 \mathrm{~g})$ were found for the southern Black Sea in this study. The mean TL of female individuals $(\bar{X}=205.26 \mathrm{~mm}$ ) was found higher than male individuals $(\bar{X}=199.10 \mathrm{~mm})$. The TL\% ratio of head length was found as $24.45 \%$ for all individuals. In this study, isometric growth $(t=2.009, p>0.05)$ was determined for all individuals and the length-weight relationship (LWR) was found as $W=0.013 T L^{3.003}\left(r^{2}=0.983\right)$. This study revealed that the morphological characteristics of $L$. mormyrus differ significantly between female and male individuals and the species may be a good example of sexual dimorphism.
\end{abstract}

Keywords: Black Sea, fish morphology, LWR, Sparid, Striped seabream

\section{INTRODUCTION}

Sparids are spread in coastal waters worldwide and sustain commercial and recreational fishing (Fischer, Schneider, \& Bauchot, 1987). The striped seabream Lithognathus mormyrus (Linnaeus, 1758) (Perciformes: Sparidae) is naturally found in the Eastern Atlantic, South Africa coastal waters, and the Western Indian Ocean. It is a demersal species living in groups over various sea bottoms, mainly sandy, seagrass beds and rocky beds to a maximum depth of eighteen meters (Bauchot \& Hureau, 1986). It feeds on crustaceans, small teleosts, and molluscs (Chessa et al., 2005). They can reach up to $55 \mathrm{~cm}$ in total length, and the highest estimated age is twelve years old (Kraljević, Dulčić, Cetinić, \& Pallaoro, 1996). Striped sea breams are hermaphrodites where juveniles are male. After $14 \mathrm{~cm}$ total length, the female character is dominant. The striped sea bream is one of the representative species of
Sparid in the Black Sea. It is known that the adaptation of species inhabiting the Mediterranean Sea (Monteiro et al., 2010) occurred by passing the Turkish Straits System to the Black Sea (Aydın, 2017). This species is also thought to have adapted to the Black Sea ecosystem in this way. The first record of this species on the Black Sea coast of Turkey was reported by Satılmış, Sümer, Aksu, and Çelik (2014) in the province of Sinop, and the second occurrence was recorded by Engin, Keskin, Akdemir, and Seyhan (2015) in the provinces of Istanbul, Trabzon, Rize and Artvin. Next, it was recorded by Aydın (2017) in the province of Ordu. It is noted, lastly, that Kasapoğlu, Çankırılıgil, Düzgüneş, Çakmak, and Eroğlu (2020), who studied biological features of the species in the Black Sea, gave important information on the bio-ecological and genetic aspects.

Morphometric studies are based on a set of measurements that are continuous data, re- 
vealing the shape variation and size (Turan, 1999). Morphological characters, such as meristic counts and body shape, have long been used in stock identification (Silva, 2003). Because it can yield information complementary, it has provided valuable results for assessing the stock structure of several species of marine fish (Schaefer, 1989). Geographic and different environmental components can vary in single morphological characteristics, growth patterns, and body shape within and among populations (Firmat, Schliewen, Losseau, \& Alibert, 2012). For fish, sexual dimorphism, generally, has been recorded in body size, fin size and shape, color pattern, and head morphology (Morbey, 2018). Females are usually larger than males of the same age, while males are larger than females for some species (Mann, 1980). Dentition, such as number, shape, and arrangement, may also be sexually dimorphic between males and females (de Santana \& Vari, 2010).

According to the FAO catch statistics, the population of $L$. mormyrus has been affected by overfishing and may also indicate a future decline. In addition, this species has a Least Concern (LC) status in the Red List of Threatened Species (Russel, Carpenter, Pollard, Mann, \& Buxton, 2014). This decline is also seen in Turkey. The total amount of striped seabream fishing in Turkey was reported as 390 tons in 2009 while it was reported as 73.9 tons in 2019 (Turkish Statistical Institute, 2019). Some studies were carried out on the distribution, biology, growth, and genetic and morphological characterization of L. mormyrus in Turkey (Türkmen \& Akyurt, 2003; Akyol, Kınacıgil, \& Şevik, 2007; Emre, Balık, Sümer, Oskay, \& Yeşilçimen, 2010; Sümer, Özdemir, \& Ertekin, 2014; Altın, Ayyıldız, Kale, \& Alver, 2015; Aydın, 2017; Kasapoğlu et al., 2020; Reis \& Ateş, 2020). In this study, we investigate the hypothesis that male and female individuals differ significantly from each other morphologically. In addition to the existing literature, we studied samples with a wider size range in $L$. mormyrus populations in the Black Sea, determined morphological differences according to gender, and evaluated the relationship of morphometric characteristics with each other. Considering the commercial importance of the species and the current critical situation, it is essential to follow and manage the population of the species. Any information about this species will shed light on the future in terms of scientific and fishery management.

\section{MATERIALS AND METHODS}

Fifty striped seabream individuals (female $=27$, male=23) were sampled along the Turkish coast of the southern Black Sea $\left(41^{\circ} 40^{\prime} 24^{\prime \prime}-41^{\circ} 26^{\prime} 10^{\prime \prime} \mathrm{N} \& 35^{\circ} 32^{\prime} 09^{\prime \prime}-41^{\circ} 22^{\prime} 00^{\prime \prime} \mathrm{E}\right)$ between January 2020 and November 2020 by using a trammel net $(300 \mathrm{~m}$ long with $44 \mathrm{~mm}$ mesh size) set at 5-20 m depths. The widest possible size range of individuals was collected from both genders to make the study representative of the entire population. Gonads were removed and identified as ovaries or testes from examinations of the gonadal tissue macroscopically. Morphological characters were measured in the laboratory with an electronic caliper to the nearest $0.01 \mathrm{~mm}$. The weight of samples was weighed to the nearest $0.01 \mathrm{~g}$. Fifteen morphometric characteristics were measured on each sample, and those are shown in Fig. 1 (Gharaei, 2012).

Body length is usually expressed as a proportion of standard (SL), fork (FL), and total length (TL). For instance, in species with rigid

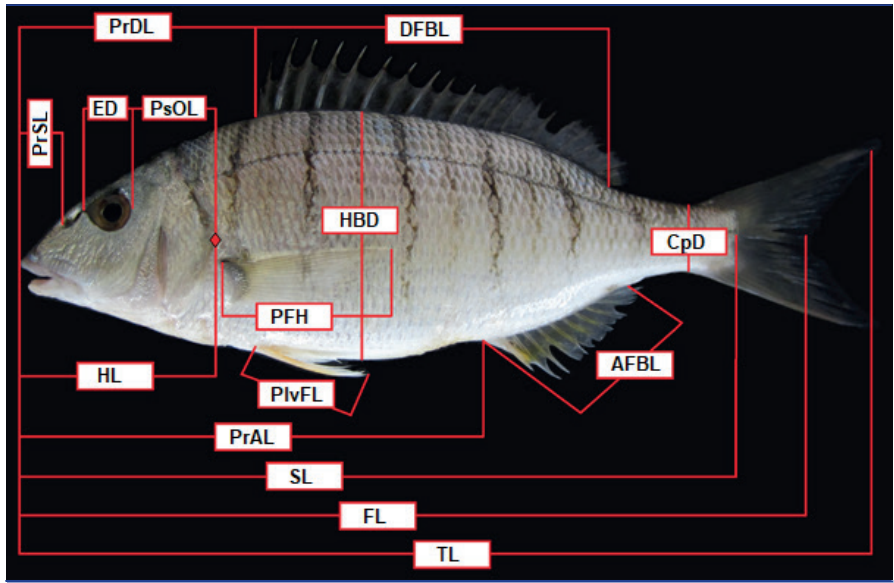

Figure 1. Morphological measurements of $L$. mormyrus. Abbreviations are presented in Table S1.

caudal fins, such as tuna and billfish, FL is frequently used. Indeed, SL is preferred in fish collections as the caudal fin becomes brittle over time and may break off. Gaygusuz et al. (2006) suggest that the use of TL had significantly lower errors compared to $\mathrm{FL}$ and SL for all species. For this reason, the TL was used on the undamaged samples for a standard body shape in this study. Different morphometric characteristics were calculated as the percentage of total length (TL\%), and the variance coefficient was determined by methods of statistical analysis by sexes. The value for the coefficient of variation (Avşar, 1998) was calculated using this formula:

$$
\text { CV } \%=\frac{\text { Standard deviation }}{\text { Mean }} \times 100
$$

Relationships between total length and weight were determined for all individuals using the equation $\mathrm{W}=\mathrm{aTL} \mathrm{L}^{\mathrm{b}}$, where $\mathrm{W}$ is the fish weight (g), TL is total length $(\mathrm{mm})$, and $a$ and $b$ are the coefficients of the functional regression between $\mathrm{W}$ and TL (Ricker, 1975). The linear relationships between $T L$ and the other morphological measurements were estimated with the power equation $Y=a+b T L$., where $Y$ is the morphological measurements $(\mathrm{mm}), \mathrm{TL}$ is the total length measurement $(\mathrm{mm})$, and $a$ and $b$ are the regression parameters as the intercept and the slope, respectively (Froese, 2006). The t-test was performed to evaluate whether the estimated $b$ values are significantly different $(p<0.05)$ from the isometric value 3 (Pauly, 1983). The $95 \%$ confidence limits (Cl) of parameters a and b were estimated, and the coefficient of determination $\left(r^{2}\right)$ was used to evaluate the correlation between TL and morphological measurements (Ricker, 1975). The distribution normality of the morphometric characteristics was analyzed using the Kolmogorov-Smirnov test, and the homogeneity was analyzed using the ANOVA (Analysis of Variance) test. The results were considered statistically significant at $p<0.05$. Thus, non-parametric analyses (Mann-Whitney U) were used for statistical tests. A hierarchical Ward cluster analysis was used to determine closely related variables after $Z$ score correction (Lopez et al., 2004). The data were analyzed by using the statistics software SPSS 26.0 and tabulated with Microsoft Excel 2019 


\section{RESULTS AND DISCUSSION}

The TL of females ranged between 160 and $310 \mathrm{~mm}$ and males between 142 and $300 \mathrm{~mm}$. The mean TL and standard error $( \pm \mathrm{SE})$ were calculated as $202.43 \pm 5.88 \mathrm{~mm}$ while the mean $\mathrm{W}$ was $119.47 \pm 12.53 \mathrm{~g}$ for all samples. The most considerable maximum length and weight values $(T L=310 \mathrm{~mm}$ for $\mathrm{W}=399.73 \mathrm{~g}$ ) were found for the southern Black Sea. The morphological measurements and statistical differences for males, females, and all indi- viduals are presented in Table 1. The mean TL of female individuals $(\bar{X}=205.26 \mathrm{~mm}$ ) was found higher than male individuals ( $\bar{X}$ $=199.10 \mathrm{~mm}$ ). It was determined that there was no statistically significant difference between the TL of female and male individuals regarding morphometric characteristics $(U=272.00 ; z=-$ $0.750 ; p>0.05$ ). Similar statistical results (Mann-Whitney $U$, $p>0.05)$ were found as the same for the other morphological characters and W (Table 1). All morphometric measurements of females were found higher than those of males. Fischer et al.

Table 1. Summary of morphometric measurements (mean \pm standard error, minimum and maximum) in $\mathrm{mm}$, and statistics of the Mann-Whitney U rank sum for females ( $\left(\right.$ ) and males ( $\left.0^{7}\right)$ of L. mormyrus.

\begin{tabular}{|c|c|c|c|c|c|c|c|c|c|c|c|c|}
\hline \multirow{2}{*}{ 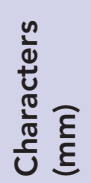 } & \multicolumn{3}{|c|}{ ᄋ $(\mathrm{N}=27)$} & \multicolumn{3}{|c|}{$\sigma^{\pi}(\mathrm{N}=23)$} & \multicolumn{3}{|c|}{$q+\sigma^{\top}(\mathrm{N}=50)$} & \multicolumn{3}{|c|}{ Statistical Analyze } \\
\hline & $\overline{\mathrm{X}} \pm \mathrm{SE}$ & Min & Max & $\bar{X} \pm S E$ & Min & Max & $\bar{X} \pm S E$ & Min & Max & U & $\mathbf{z}$ & $\begin{array}{c}\mathrm{p}- \\
\text { value }\end{array}$ \\
\hline $\mathrm{TL}$ & $205.26 \pm 8.19$ & 160.00 & 310.00 & $199.10 \pm 8.55$ & 142.00 & 300.00 & $202.43 \pm 5.88$ & 142.00 & 310.00 & 272.00 & -0.750 & $0.453^{\mathrm{ns}}$ \\
\hline $\mathrm{FL}$ & $184.12 \pm 7.14$ & 146.00 & 280.00 & $177.98 \pm 7.25$ & 130.00 & 267.00 & $181.29 \pm 5.07$ & 130.00 & 280.00 & 283.00 & -0.536 & $0.592^{\text {ns }}$ \\
\hline$S L$ & $168.07 \pm 6.56$ & 134.00 & 255.00 & $160.87 \pm 7.04$ & 105.00 & 247.00 & $164.76 \pm 4.78$ & 105.00 & 255.00 & 274.50 & -0.701 & $0.483^{\text {ns }}$ \\
\hline ED & $10.44 \pm 0.35$ & 8.00 & 14.80 & $9.86 \pm 0.26$ & 8.00 & 12.50 & $10.17 \pm 0.22$ & 8.00 & 14.80 & 266.50 & -0.861 & $0.389^{\text {ns }}$ \\
\hline $\operatorname{PrSL}$ & $16.63 \pm 0.96$ & 12.00 & 30.20 & $15.63 \pm 0.99$ & 10.00 & 29.80 & $16.17 \pm 0.69$ & 10.00 & 30.20 & 247.00 & -1.238 & $0.216^{\text {ns }}$ \\
\hline $\mathrm{PsOL}$ & $19.49 \pm 0.79$ & 15.00 & 30.50 & $19.47 \pm 0.78$ & 15.00 & 29.00 & $19.48 \pm 0.55$ & 15.00 & 30.50 & 307.50 & -0.058 & $0.953^{\text {ns }}$ \\
\hline $\operatorname{PrDL}$ & $64.02 \pm 2.63$ & 50.00 & 102.90 & $60.87 \pm 2.57$ & 45.20 & 96.00 & $62.57 \pm 1.84$ & 45.20 & 102.90 & 266.00 & -0.867 & $0.386^{\text {ns }}$ \\
\hline DFBL & $80.45 \pm 3.37$ & 62.50 & 124.28 & $78.36 \pm 3.59$ & 60.20 & 126.00 & $79.49 \pm 2.44$ & 60.20 & 126.00 & 282.00 & -0.555 & $0.579^{\text {ns }}$ \\
\hline PrAL & $108.92 \pm 4.64$ & 83.80 & 170.00 & $105.13 \pm 4.47$ & 81.10 & 157.00 & $107.18 \pm 3.22$ & 81.10 & 170.00 & 275.00 & -0.692 & $0.489^{\text {ns }}$ \\
\hline $\mathrm{HBD}$ & $55.90 \pm 2.21$ & 43.00 & 86.70 & $52.50 \pm 2.09$ & 40.70 & 81.00 & $54.34 \pm 1.54$ & 40.70 & 86.70 & 246.50 & -1.246 & $0.213^{\text {ns }}$ \\
\hline CpD & $13.80 \pm 0.57$ & 11.00 & 21.81 & $13.62 \pm 0.66$ & 10.20 & 23.00 & $13.72 \pm 0.43$ & 10.20 & 23.00 & 293.00 & -0.342 & $0.733^{\text {ns }}$ \\
\hline W & $123.75 \pm 18.62$ & 59.67 & 399.73 & $114.44 \pm 16.63$ & 38.40 & 336.39 & $119.47 \pm 12.53$ & 38.40 & 399.73 & 273.00 & -0.730 & $0.465^{\text {ns }}$ \\
\hline
\end{tabular}

Table 2. Summary of morphometric measurements (mean \pm standard error) in TL\%, and statistics of the rank sum of L. mormyrus.

\begin{tabular}{|c|c|c|c|c|c|c|c|c|c|}
\hline \multirow{2}{*}{ 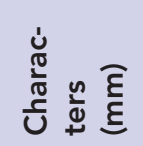 } & \multicolumn{2}{|l|}{ ㅇ $(\mathrm{N}=27)$} & \multicolumn{2}{|l|}{$\sigma^{\pi}(\mathrm{N}=23)$} & \multicolumn{2}{|l|}{$++0^{\pi}(N=50)$} & \multicolumn{3}{|c|}{ Statistical Analyze } \\
\hline & $\bar{X} \pm S E(\min -\max )$ & $\mathrm{Cv} \%$ & $\bar{X} \pm S E(\min -\max )$ & $\mathrm{Cv} \%$ & $\bar{X} \pm S E(\min -\max )$ & $\mathrm{C} v \%$ & U & $\mathbf{z}$ & $\begin{array}{c}\mathrm{p}- \\
\text { value }\end{array}$ \\
\hline FL (TL\%) & $89.79 \pm 0.23(88.01-92.91)$ & 1.35 & $89.56 \pm 0.34(85.37-92.63)$ & 1.83 & $89.69 \pm 0.20(85.37-92.91)$ & 1.58 & 301.50 & -0.175 & $0.861^{n=}$ \\
\hline SL (TL\%) & $81.95 \pm 0.16(79.71-83.75)$ & 1.04 & $80.76 \pm 0.52(73.94-83.50)$ & 3.11 & $81.40 \pm 0.27(73.94-83.75)$ & 2.32 & 249.00 & -0.197 & $0.231^{\mathrm{ns}}$ \\
\hline HL (TL\%) & $24.36 \pm 0.23(19.80-26.26)$ & 4.81 & $24.56 \pm 0.15(23.31-26.76)$ & 3.01 & $24.45 \pm 0.14(19.80-26.76)$ & 4.05 & 293.00 & -0.341 & $0.733^{\mathrm{ns}}$ \\
\hline $\mathrm{ED}$ (TL\%) & $5.13 \pm 0.09(4.16-5.94)$ & 8.79 & $5.02 \pm 0.09(4.14-5.64)$ & 8.23 & $5.08 \pm 0.06(4.14-5.94)$ & 8.52 & 275.50 & -0.681 & $0.496^{\text {ns }}$ \\
\hline $\operatorname{PrSL}(T L \%)$ & $7.99 \pm 0.12(7.34-9.74)$ & 7.92 & $7.75 \pm 0.14(6.96-9.93)$ & 8.60 & $7.88 \pm 0.09(6.96-9.93)$ & 8.29 & 199.00 & -2.171 & 0.030 * \\
\hline $\mathrm{PsOL}$ (TL\%) & $9.50 \pm 0.10(8.76-11.17)$ & 5.29 & $9.82 \pm 0.14(9.11-11.64)$ & 6.76 & $9.65 \pm 0.08(8.76-11.64)$ & 6.20 & 219.50 & -1.772 & $0.076^{\mathrm{ns}}$ \\
\hline $\operatorname{PrDL}(T L \%)$ & $31.18 \pm 0.17(29.19-33.19)$ & 2.90 & $30.65 \pm 0.35(25.26-32.92)$ & 5.52 & $30.94 \pm 0.19(25.26-33.19)$ & 4.32 & 264.00 & -0.905 & $0.365^{\mathrm{ns}}$ \\
\hline DFBL (TL\%) & $39.13 \pm 0.18(37.80-41.99)$ & 2.35 & $39.30 \pm 0.26(37.04-42.39)$ & 3.20 & $39.21 \pm 0.15(37.04-42.39)$ & 2.75 & 285.00 & -0.496 & $0.620^{\mathrm{ns}}$ \\
\hline $\operatorname{PrAL}(T L \%)$ & $52.95 \pm 0.17(51.51-54.84)$ & 1.66 & $52.84 \pm 0.26(50.86-57.11)$ & 2.40 & $52.90 \pm 0.15(50.86-57.11)$ & 2.02 & 275.00 & -0.691 & $0.489^{\text {ns }}$ \\
\hline AFBL (TL\%) & $14.22 \pm 0.12(13.34-15.87)$ & 4.45 & $14.39 \pm 0.15(13.51-16.50)$ & 4.99 & $14.30 \pm 0.10(13.34-16.50)$ & 4.70 & 265.50 & -0.973 & $0.330^{\mathrm{ns}}$ \\
\hline PFH (TL\%) & $16.96 \pm 0.14(14.71-18.65)$ & 4.28 & $16.82 \pm 0.12(16.00-18.17)$ & 3.47 & $16.90 \pm 0.09(14.71-18.65)$ & 3.92 & 240.50 & -1.363 & $0.173^{n s}$ \\
\hline PlvFL (TL\%) & $12.49 \pm 0.07(11.53-13.30)$ & 3.07 & $12.52 \pm 0.10(11.33-13.45)$ & 3.87 & $12.50 \pm 0.06(11.33-13.45)$ & 3.43 & 291.00 & -0.380 & $0.704^{\text {ns }}$ \\
\hline HBD (TL\%) & $27.28 \pm 0.29(25.38-32.18)$ & 5.47 & $26.46 \pm 0.23(24.39-28.72)$ & 4.23 & $26.90 \pm 0.20(24.39-32.18)$ & 5.14 & 205.00 & -2.054 & 0.040 * \\
\hline CpD (TL\%) & $6.72 \pm 0.04(6.35-7.13)$ & 2.71 & $6.82 \pm 0.06(6.32-7.67)$ & 4.14 & $6.77 \pm 0.03(6.32-7.67)$ & 3.51 & 233.00 & -1.509 & $0.131^{\mathrm{ns}}$ \\
\hline
\end{tabular}


(1987) reported that striped seabream generally grow up to 30 $\mathrm{cm}$ but can reach a length (TL) of $55 \mathrm{~cm}$. Satılmış et al. (2014), Engin et al. (2015), Aydın (2018), and Kasapoğlu et al. (2020), in their studies in the Black Sea, reported that the TL of individuals was $25.4,22.6,30.0$, and $23.5 \mathrm{~cm}$, respectively. In the Atlantic Ocean, Dorel (1986) observed the biggest individuals, with a TL of 52.5 $\mathrm{cm}$, in the Bay of Biscay. Kraljević et al. (1996) observed that individual striped seabream from the northern Adriatic Sea reached a length of $38 \mathrm{~cm}$. Monteiro et al. (2010) observed the heaviest individual with a weight of $895.4 \mathrm{~g}$ and a TL of $42.7 \mathrm{~cm}$ in their study in Portugal. We found the mean TL and the mean $\mathrm{W}$ as $202.43 \pm 5.88 \mathrm{~mm}$ and $119.47 \pm 12.53 \mathrm{~g}$ for all samples, respectively. In general, it can be argued that the growth of $L$. mormyrus in the Mediterranean and the Atlantic Ocean is faster than that in the Black Sea. Kasapoğlu et al. (2020) determined a significant differentiation between three populations (Black Sea, Mediterranean and the Aegean Sea) of L. mormyrus. All morphometric measurements of females were found higher than males in this study. Females are usually larger than males of the same age (Mann, 1980). Kasapoğlu et al. (2020) determined an opposite situation in their studies and found that all morphological measurements of males were higher than females in the same species.

The original TL was considered in the morphometric evaluations, and the other characteristics are presented as a percentage of total length (TL\%) as shown in Table 2. According to the values, the most variable features were ED and PrSL in females and males while the least variable features were the $\mathrm{SL}$ in females and the FL in males. The TL\% ratio of HL was found as $24.45 \%$ for all individuals. Although TL\% ratios of males were found than those of females, HL, PsOL, DFBL, AFBL, PlvFL, and CpD have a higher rate in females. When looking in more detail, it is seen that fin lengths mostly caused these differences for females. It was determined that there was no statistically significant difference between the TL\% of female and male individuals regarding the morphometric characteristics, excluding PrSL and HBD. The TL\% ratio of head length was found as $24.45 \%$ for all individuals. It was observed that the head makes up almost a quarter of the body. Sparids, such as striped seabream, possess a longer body, a larger mouth gap, a relatively larger head region, and a caudal peduncle which is longer and narrower (Costa \& Cataulle, 2007). The pelvic fin was found as approximately $13 \%$ of the TL for the combined samples. Pectoral fins are used for balance, deceleration, and partial displacement. In addition, they act as a brake in forward movement, rotation, and sudden stops. Sparids have a long dorsal fin, and it is about $40 \%$ of its full neck. The dorsal fin is a median fin located on the dorsal side of the fish. It starts at the level of the pectoral fin base and ends at the level where the pelvic fin ends towards the tail. This fin helps the fish swim in a balanced way and is also used in sudden changes of direction. These features are seen in all members of the Sparidae family (Pervin, 2007). It was determined that there was a statistically significant difference between the TL\% of PrSL and HBD for both sexes. The morphological discrepancy in the head region was highlighted in several marine fish such as carangids (Turan, 2004), gobies (Mejri, Lo Brutto, Hassine, Arculeo, \& Ben Hassine, 2012), and Sparids (Palma \& Andrade, 2002). However, the $p$ values were found high for $F L, H L, P l v F L$. and DFBL, and this situation
Table S1. Description of measured morphological characters of L. mormyrus.

\begin{tabular}{|c|c|c|}
\hline Abbreviations & Character & Description \\
\hline $\mathrm{TL}$ & $\begin{array}{l}\text { Total } \\
\text { length }\end{array}$ & $\begin{array}{l}\text { The longest distance be- } \\
\text { tween the tip of the snout } \\
\text { and the end of the tail }\end{array}$ \\
\hline $\mathrm{FL}$ & $\begin{array}{l}\text { Fork } \\
\text { length }\end{array}$ & $\begin{array}{l}\text { Distance from the tip of the } \\
\text { nose to the middle part of } \\
\text { the caudal fin }\end{array}$ \\
\hline SL & $\begin{array}{l}\text { Standard } \\
\text { length }\end{array}$ & $\begin{array}{l}\text { Distance from the tip of the } \\
\text { nose to the middle part of the } \\
\text { end of the vertebral column }\end{array}$ \\
\hline $\mathrm{HL}$ & $\begin{array}{l}\text { Head } \\
\text { length }\end{array}$ & $\begin{array}{l}\text { Distance from the tip of snout } \\
\text { to the upper posterior to gill } \\
\text { cover }\end{array}$ \\
\hline ED & $\begin{array}{l}\text { Eye } \\
\text { diameter }\end{array}$ & $\begin{array}{l}\text { The maximum diameter of } \\
\text { the eye with parallel to the } \\
\text { longitudinal axis of the body }\end{array}$ \\
\hline PrSL & $\begin{array}{l}\text { Pre-snout } \\
\text { length }\end{array}$ & $\begin{array}{l}\text { Distance from the tip of the } \\
\text { nose to the front nostril }\end{array}$ \\
\hline $\mathrm{PsOL}$ & $\begin{array}{l}\text { Post-or- } \\
\text { bital } \\
\text { length }\end{array}$ & $\begin{array}{l}\text { Distance from the end of the } \\
\text { orbit to the posterior margin } \\
\text { of the operculum }\end{array}$ \\
\hline PrDL & $\begin{array}{l}\text { Pre-dorsal } \\
\text { length }\end{array}$ & $\begin{array}{l}\text { Distance from tip of snout to } \\
\text { anterior margin of the dorsal } \\
\text { fin base }\end{array}$ \\
\hline DFBL & $\begin{array}{l}\text { Dorsal } \\
\text { fin base } \\
\text { length }\end{array}$ & $\begin{array}{l}\text { The longest horizontal dis- } \\
\text { tance of the dorsal fin base }\end{array}$ \\
\hline PrAL & $\begin{array}{l}\text { Pre-anal } \\
\text { length }\end{array}$ & $\begin{array}{l}\text { Distance from tip of snout to } \\
\text { anterior margin of the anal } \\
\text { fin base }\end{array}$ \\
\hline AFBL & $\begin{array}{l}\text { Anal fin } \\
\text { base } \\
\text { length }\end{array}$ & $\begin{array}{l}\text { The longest horizontal dis- } \\
\text { tance of the anal fin base }\end{array}$ \\
\hline PFH & $\begin{array}{l}\text { Pectoral } \\
\text { fin height }\end{array}$ & $\begin{array}{l}\text { Distance from the lower } \\
\text { end to the upper end of the } \\
\text { pectoral fin }\end{array}$ \\
\hline PlvFL & $\begin{array}{l}\text { Pelvic fin } \\
\text { length }\end{array}$ & $\begin{array}{l}\text { Distance from the lower end } \\
\text { to the upper end of the pelvic } \\
\text { fin }\end{array}$ \\
\hline $\mathrm{HBD}$ & $\begin{array}{l}\text { Highest } \\
\text { body } \\
\text { depth }\end{array}$ & $\begin{array}{l}\text { The deepest distance from } \\
\text { the lower end to the upper } \\
\text { end of the body }\end{array}$ \\
\hline CpD & $\begin{array}{l}\text { Caudal } \\
\text { peduncle } \\
\text { depth }\end{array}$ & $\begin{array}{l}\text { The minimum depth of the } \\
\text { caudal peduncle }\end{array}$ \\
\hline
\end{tabular}

showed that head and fin length might differ by sex. Similarly, Morbey (2018) reported that sexual differences were generally seen in fin size and head morphology. It may occur because aquatic environments present different characteristics, habitats, or diets (Delariva \& Agostinho, 2001).

The statistical data relevant for the evaluation of the linear relationships of each characteristic with TL are included in Table 3, showing the estimated regression parameters along with their 
Table 3. Length-weight relationship (LWR) and relationship of morphological characters with total length (TL) of L. mormyrus.

\begin{tabular}{|c|c|c|c|c|c|c|c|c|c|}
\hline & \multirow{2}{*}{ Sex } & \multirow{2}{*}{$r^{2}$} & \multirow{2}{*}{ a } & \multicolumn{2}{|c|}{$95 \% \mathrm{Cl}(\mathrm{a})$} & \multirow{2}{*}{ b } & \multicolumn{2}{|c|}{$95 \% \mathrm{Cl}$ (a) } & \multirow{2}{*}{$p$} \\
\hline & & & & $\min$ & $\max$ & & $\min$ & $\max$ & \\
\hline & 우 & 0.996 & 5.500 & 0.776 & 10.223 & 0.870 & 0.848 & 0.893 & \\
\hline \multirow[t]{3}{*}{ TL-FL } & $0^{\pi}$ & 0.993 & 9.728 & 3.110 & 16.346 & 0.845 & 0.812 & 0.878 & $p<0.05$ \\
\hline & o $+0^{\pi}$ & 0.994 & 7.225 & 3.347 & 11.104 & 0.860 & 0.841 & 0.879 & \\
\hline & 웅 & 0.997 & 3.868 & 0.397 & 7.340 & 0.800 & 0.783 & 0.817 & \\
\hline \multirow[t]{3}{*}{ TL-SL } & $0^{*}$ & 0.980 & -1.301 & -12.073 & 9.471 & 0.815 & 0.761 & 0.868 & $p<0.05$ \\
\hline & $q+\sigma^{*}$ & 0.988 & 1.117 & -4.131 & 6.365 & 0.808 & 0.783 & 0.834 & \\
\hline & ㅇ & 0.959 & -4.492 & -9.236 & 0.253 & 0.266 & 0.243 & 0.289 & \\
\hline \multirow[t]{3}{*}{ TL-HL } & $0^{\pi}$ & 0.984 & 1.221 & -1.631 & 4.074 & 0.239 & 0.225 & 0.253 & $p<0.05$ \\
\hline & $q+0^{*}$ & 0.966 & -1.883 & -4.752 & 0.987 & 0.254 & 0.240 & 0.268 & \\
\hline & ᄋ & 0.799 & 2.669 & 1.032 & 4.307 & 0.038 & 0.030 & 0.046 & \\
\hline \multirow{3}{*}{ TL-ED } & $0^{\pi}$ & 0.879 & 4.208 & 3.237 & 5.178 & 0.028 & 0.024 & 0.033 & $p<0.05$ \\
\hline & $q+0^{*}$ & 0.799 & 3.286 & 2.264 & 4.308 & 0.034 & 0.029 & 0.039 & \\
\hline & 甲 & 0.967 & -7.100 & -8.934 & -5.265 & 0.116 & 0.107 & 0.124 & \\
\hline \multirow[t]{3}{*}{ TL-PrSL } & $0^{\pi}$ & 0.945 & -6.688 & -9.183 & -4.193 & 0.112 & 0.100 & 0.124 & $p<0.05$ \\
\hline & $\rho+0^{*}$ & 0.957 & -6.973 & -8.426 & -5.519 & 0.114 & 0.107 & 0.121 & \\
\hline & 甲 & 0.929 & 0.420 & -1.794 & 2.634 & 0.093 & 0.082 & 0.104 & \\
\hline \multirow[t]{3}{*}{ TL-PsOL } & $0^{*}$ & 0.900 & 2.344 & -0.299 & 4.988 & 0.086 & 0.073 & 0.099 & $p<0.05$ \\
\hline & $q+\sigma^{*}$ & 0.911 & 1.383 & -0.289 & 3.056 & 0.089 & 0.081 & 0.098 & \\
\hline & o & 0.976 & -0.958 & -5.283 & 3.367 & 0.317 & 0.296 & 0.337 & \\
\hline \multirow[t]{3}{*}{ TL-PrDL } & $0^{*}$ & 0.921 & 3.464 & -4.301 & 11.229 & 0.288 & 0.250 & 0.327 & $p<0.05$ \\
\hline & $q+0^{*}$ & 0.950 & 0.772 & -3.440 & 4.984 & 0.305 & 0.285 & 0.326 & \\
\hline & 우요 & 0.989 & -3.466 & -7.174 & 0.242 & 0.409 & 0.391 & 0.427 & \\
\hline \multirow[t]{3}{*}{ TL-DFBL } & $0^{*}$ & 0.979 & -4.416 & -10.058 & 1.227 & 0.416 & 0.388 & 0.444 & $p<0.05$ \\
\hline & $\phi+0^{*}$ & 0.984 & -3.805 & -6.925 & -0.685 & 0.411 & 0.396 & 0.427 & \\
\hline & q & 0.996 & -7.266 & -10.281 & -4.251 & 0.566 & 0.552 & 0.580 & \\
\hline \multirow[t]{3}{*}{ TL-PrAL } & $0^{\pi}$ & 0.990 & 1.515 & -3.402 & 6.432 & 0.520 & 0.496 & 0.545 & $p<0.05$ \\
\hline & $q+\sigma^{\pi}$ & 0.992 & -3.418 & -6.392 & -0.445 & 0.546 & 0.532 & 0.561 & \\
\hline & ㅇ & 0.959 & -1.542 & -4.210 & 1.127 & 0.150 & 0.137 & 0.163 & \\
\hline \multirow[t]{3}{*}{ TL-AFBL } & $0^{\pi}$ & 0.949 & -0.593 & -3.728 & 2.543 & 0.147 & 0.132 & 0.162 & $p<0.05$ \\
\hline & $q+0^{*}$ & 0.954 & -1.051 & -3.001 & 0.899 & 0.148 & 0.139 & 0.158 & \\
\hline & q & 0.970 & -4.391 & -7.295 & -1.487 & 0.192 & 0.178 & 0.206 & \\
\hline \multirow[t]{3}{*}{ TL-PFH } & $0^{\pi}$ & 0.974 & -0.829 & -3.431 & 1.772 & 0.172 & 0.160 & 0.185 & $p<0.05$ \\
\hline & $q+\sigma^{\pi}$ & 0.969 & -2.862 & -4.839 & -0.886 & 0.184 & 0.174 & 0.193 & \\
\hline & ९ & 0.982 & 3.371 & 2.097 & 4.645 & 0.108 & 0.102 & 0.114 & \\
\hline \multirow[t]{3}{*}{ TL-PlvFL } & $0^{\pi}$ & 0.986 & 4.966 & 3.872 & 6.060 & 0.099 & 0.094 & 0.105 & $p<0.05$ \\
\hline & $q+0^{\pi}$ & 0.982 & 4.060 & 3.205 & 4.915 & 0.104 & 0.100 & 0.108 & \\
\hline & ९ & 0.924 & 2.681 & -3.749 & 9.112 & 0.259 & 0.229 & 0.290 & \\
\hline \multirow[t]{3}{*}{ TL-HBD } & $0^{\pi}$ & 0.957 & 4.815 & 0.137 & 9.494 & 0.239 & 0.216 & 0.263 & $p<0.05$ \\
\hline & $q+0^{\pi}$ & 0.930 & 3.272 & -0.893 & 7.436 & 0.252 & 0.232 & 0.272 & \\
\hline & 우요 & 0.981 & -0.423 & -1.250 & 0.405 & 0.069 & 0.065 & 0.073 & \\
\hline \multirow[t]{3}{*}{ TL-CpD } & $0^{\pi}$ & 0.964 & -1.416 & -2.761 & -0.072 & 0.076 & 0.069 & 0.082 & $p<0.05$ \\
\hline & $q+0^{*}$ & 0.969 & -0.815 & -1.584 & -0.046 & 0.072 & 0.068 & 0.076 & \\
\hline & ○ & 0.983 & 0.013 & 0.008 & 0.021 & 2.986 & 8.824 & 3.147 & \\
\hline TL-W & $0^{*}$ & 0.984 & 0.012 & 0.007 & 0.020 & 3.032 & 2.857 & 3.207 & $p<0.05$ \\
\hline & $q+0^{*}$ & 0.983 & 0.013 & 0.009 & 0.018 & 3.003 & 2.889 & 3.116 & \\
\hline
\end{tabular}


Table 4. Proximity matrix of morphometric variables for L. mormyrus.

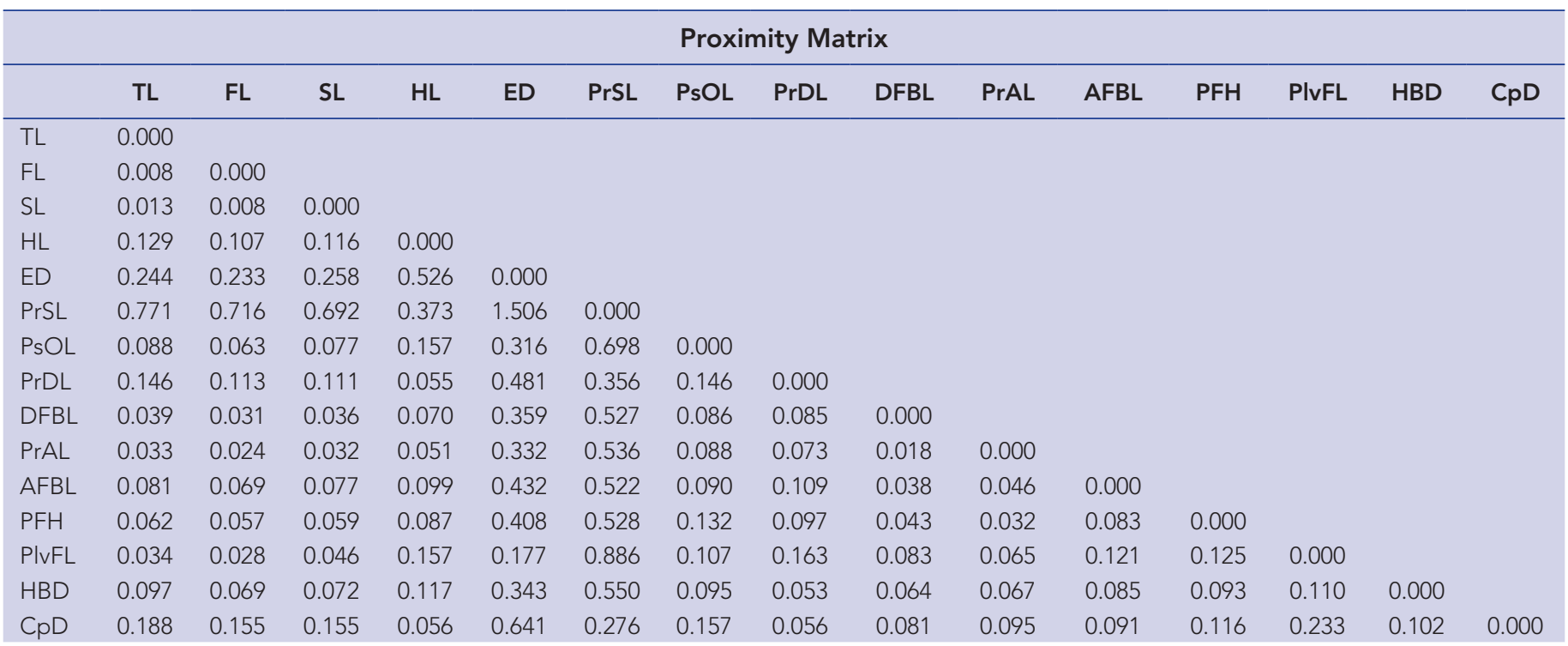

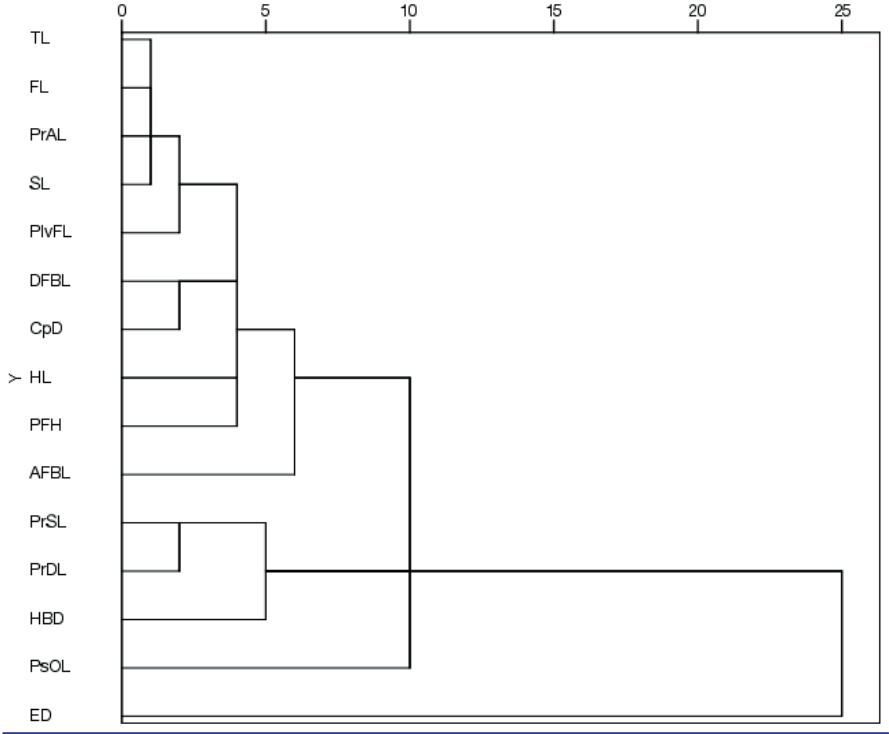

Figure 2. Dendrogram topology of the morphometric variables of L. mormyrus.

95\% confidence interval and the coefficient of correlation. The linear regression equations are found highly significant with $r^{2}$ values ranged from 0.799 to 0.997 for females while $r^{2}$ values ranged from 0.879 to 0.993 for males. The interrelationships among the length parameters with TL are also found at high values with all $r^{2}$ values being $>0.90$, excluding ED. Among the linear regression values, the morphometric characteristic most closely related to TL was determined as FL $\left(r^{2}=0.994\right)$, and the weakest correlation was defined as the ED $\left(r^{2}=0.799\right)$. It was determined that the correlation between morphometric characteristics and TL was statistically similar in female and male individuals $(p<0.05)$. As a result of the proximity matrix and cluster analysis, it was determined that there were very close relationships between TL and FL (0.008), TL and SL (0.013), and FL and SL (0.008). However, there appeared to be weak relationships of ED and $\operatorname{PrSL}$ with other variables, a tendency very similar to that presented by the correlation analysis (Fig. 2; Table 4). These findings were similar to that shown by the correlation analysis (Table 3).

The expected range for the a value was reported between 0.001 and 0.05 for the natural fish populations by Froese (2006). In this study, the value was calculated as 0.013 and 0.012 for females and males, respectively. According to the $b$ value obtained from the length-weight relationship (LWR) equations, Pauly's t-test result showed that $L$. mormyrus $(t=2.009, p>0.05)$ exhibits isometric growth $(b=3)$. The LWR was found as $W=0.013 T L^{3.003}\left(r^{2}=0.983\right)$. The high value of the coefficient of determination $\left(r^{2}>0.95\right)$ was determined for L. mormyrus. The b value, one of the parameters of the LWR in fish, provides information about the environmental conditions and the body shape of the fish (Avşar, 1998). It is reported that this value varies depending on many conditions such as the number of samples, sampling season, characteristics of the aquatic ecosystem, gonadosomatic index value, and nutrition (Bagenal \& Tesch, 1978). In this study, the b value was calculated as 3.003 for all individuals, and it being over three indicates that the sampled fish have sufficiently good environmental conditions and that total growth was achieved as required. In Turkey, most of the researchers (Türkmen \& Akyurt, 2003; Akyol et al., 2007; Gökçe, Aydın, \& Metin, 2007; Illkyaz, Metin, Soykan, \& Kınacıgil, 2008; Emre et al., 2010; Acarlı, Kara, \& Bayhan, 2014) have reported positive allometry growth for $L$. mormyrus whereas some of the researchers (Bilge, Yapıcı, Filiz, \& Cerim, 2014; Sümer et al., 2014; Altın et al., 2015; Aydın, 2017; Aydın \& Sözer, 2019; Reis \& Ateş, 2020) have reported negative allometry growth. The relationship between a specimen length and its weight varies over time and between locations, depending on the abundance of food, temperature, salinity, or reproductive activity (Yankova, 2016). It is thought that conditions such as physical and chemical characteristics of water systems, the genetic structure of populations, competition between species, and pressure from fisheries may affect regional differences. The LWR of fish may be influenced by geographical location, environmental conditions, sex, and matu- 
rity (Bagenal \& Tesch, 1978). The high value of the coefficient of determination ( $\left.r^{2}>0.95\right)$ was determined for L. mormyrus. The $r^{2}$ value was reported as 0.817 for the same species by Aydın (2017) and reported relatively lower values. According to the literature, the $r^{2}$ values in the present study were similar, which may be based on many factors such as season, region, length range, fish physiology, sampling size, and habitat (Froese, 2006).

\section{CONCLUSION}

This paper represents a study to determine morphological characterization and to investigate shape differences by sex in the southern Black Sea coast populations of L. mormyrus, which cover all months, comparatively. As such, the values represent reference data for the Sparid species. Furthermore, the study can serve as a reference for future investigation in terms of scientific studies and fishery management. Although this is a local study, our results can be generalized to understand the biological and ecological aspects of L. mormyrus.

Conflict of interests: The authors declare that for this article, they have no actual, potential, or perceived conflict of interests.

Ethics committee approval: Ethics committee approval is not required. All authors declare that this study does not include any experiments with human or animal subjects.

Funding: No funding was received to assist with the preparation of this manuscript.

\section{Acknowledgement: -}

\section{Disclosure: - \\ REFERENCES}

Acarlı, D., Kara, A., \& Bayhan, B. (2014). Length-weight relations for 29 fish Species from Homa Lagoon, Aegean Sea, Turkey. Acta Ichthyologica et Piscatoria, 44, 249-257. [CrossRef]

Akyol, O., Kınacıgil, H. T., \& Şevik, R. (2007). Longline fishery and lengthweight relationships for selected fish species in Gökova Bay (Aegean Sea, Turkey). International Journal of Natural and Engineering Sciences, 1, 1-4.

Altın, A., Ayyıldız, H., Kale, S., \& Alver, C. (2015). Length-weight relationships of 49 fish species from shallow waters of Gökçeada Island, Northern Aegean Sea. Turkish Journal of Zoology, 39, 1-5. [CrossRef]

Avşar, D. (1998). Balıkçılık biyolojisi ve popülasyon dinamiği. Adana, Turkey: Baki Kitabevi.

Aydın, M. (2017). Presence of the Striped Seabream (Lithognathus mormyrus) in the Black Sea. Turkish Journal of Maritime and Marine Sciences, 3, 49-54.

Aydın, M. (2018). The new maximum length of the striped sea bream (Lithognathus mormyrus L., 1758) in the Black Sea region. Aquatic Sciences and Engineering, 33, 50-52. [CrossRef]

Aydın, M., \& Sözer, A. (2019). The length-weight relationship and condition factor of striped sea bream Lithognathus mormyrus (L., 1758) in the southern Black Sea Region. Journal of Anatolian Environmental and Animal Sciences, 4, 319-324. [CrossRef]

Bagenal, T. B., \& Tesch, F. W. (1978). Age and growth. In T. B. Bagenal (Ed.), Methods for assessment of fish production in freshwater (pp. 101-136). Oxford, England: Blackwell Science Publications.

Bauchot, M. L., \& Hureau, J. C. (1986). Sparidae, In P. J. P. Whitehead, M. L. Bauchot, J. C. Hureau, J. Nielsen, \& E. Tortonese (Eds.), Fishes of the North- Eastern Atlantic and the Mediterranean, Vol. II (pp. 883-907). Paris, France: UNESCO. [CrossRef]

Bilge, G., Yapıcı, S., Filiz, H., \& Cerim, H. (2014). Weight-length relations for 103 fish species from the southern Aegean Sea, Turkey. Acta Ichthyologica et Piscatoria, 44, 263-269. [CrossRef]

Chessa, L. A., Lanera, P., Pais, A., Plastina, N., Scardi, M., Serra, S., ... Vinci, D. (2005). Aspects of the diet of Lithognathus mormyrus (Linnaeus, 1758) in the Calich pond (northwestern Sardinia). Biologia Marina Mediterranea, 12: 492-495.

Costa, C., \& Cataudella, S. (2007). Relationship between shape and trophic ecology of selected species of Sparids of the Caprolace coastal lagoon (Central Tyrrhenian sea). Environmental Biology of Fishes, 78, 115-123. [CrossRef]

de Santana, C. D., \& Vari, R. P. (2010). Electric fishes of the genus Sternarchorhynchus (Teleostei, Ostariophysi, Gymnotiformes); phylogenetic and revisionary studies. Zoological Journal of the Linnean Society, 159, 223-371. [CrossRef]

Delariva, R. L., \& Agostinho, A. A. (2001). Relationship between morphology and diets of six neotropical loricariids. Journal of Fish Biology, 58, 832-847. [CrossRef]

Dorel, D. (1986). Poissons de l'Atlantique nordest: relations taillepoids. Nantes, France: French Research Institute for the Exploitation of the Sea.

Emre, Y., Balık, I., Sümer, Ç., Oskay, D. A., \& Yeşilçimen, Ö. (2010). Age, growth, length-weight relationship and reproduction of the striped sea bream (Lithognathus mormyrus L., 1758) (Sparidae) in the Beymelek lagoon (Antalya, Turkey). Turkish Journal of Zoology, 34, 93-100. https://doi.org/10.3906/zoo-0808-13

Engin, S., Keskin, A. C., Akdemir, T., \& Seyhan, D. (2015). Occurrence and new geographical record of striped seabream Lithognathus mormyrus (Linnaeus, 1758) in the Turkish coast of Black Sea. Turkish Journal of Fisheries and Aquatic Sciences, 15, 937-940. [CrossRef]

Firmat, C., Schliewen, U. K., Losseau, M., \& Alibert, P. (2012) Body shape differentiation at global and local geographic scales in the invasive cichlid Oreochromis mossambicus. Biological Journal of the Linnean Society, 105, 369-381. [CrossRef]

Fischer, W., Schneider, M., \& Bauchot, M. L. (1987). Méditerranée et Mer Noire (Zone de Pêche 37). Rome, Italy: FAO

Froese, R. (2006). Cube law, condition factor and weight-length relationships: history, meta-analysis and recommendations. Journal of Applied Ichthyology, 22, 241-2530. [CrossRef]

Gaygusuz, Ö., Gürsoy, Ç., Özuluğ, M., Tarkan, A. S., Acıpınar, H., Bilge, G., \& Filiz, H. (2006). Conversions of total, fork and standard length measurements based on 42 marine and fresh water fish species (from Turkish waters). Turkish Journal of Fisheries and Aquatic Sciences, 6, 79-84.

Gharaei, A. (2012). Morphometric and meristic studies of snow trout Schizothorax zarudnyi (Nikolskii, 1897) as a threatened endemic fish. World Journal of Fish and Marine Sciences, 4, 426-429. https://doi. org/10.5829/idosi.wjfms.2012.04.04.63123

Gökçe, G., Aydın, I., \& Metin, C. (2007). Length-weight relationships of 7 fish species from the North Aegean Sea, Turkey. International Journal of Natural and Engineering Sciences, 1, 51-52.

Illkyaz, A. T., Metin, G., Soykan, O., \& Kınacıgil, H. T. (2008). Length-weight relationship of 62 fish species from the Central Aegean Sea, Turkey. Journal of Applied Ichthyology, 24, 699-702. [CrossRef]

Kasapoğlu, N., Çankırılıgil, E. C., Düzgüneş, Z. D., Çakmak, E., \& Eroğlu, $O$. (2020). The bio-ecological and genetic characteristics of sand steenbras (Lithognathus mormyrus) in the Black Sea. Journal of the Black Sea/Mediterranean Environment, 26, 249-262.

Kraljević, M., Dulčić, J., Cetinić, P., \& Pallaoro, A. (1996). Age, growth and mortality of the striped sea bream, Lithognathus mormyrus L., in the northern Adriatic. Fisheries Research, 28, 361-370. [CrossRef]

Lopez, F. J. S., Garcia, M. D. G., Vidal, J. L. M., Aguilera, P. A., Garrido 
Frenich, A. (2004). Assessment of metal contamination in Donana National Park (Spain) using crayfish (Procamburus clarkii). Environmental Monitoring and Assessment, 93, 17-29. [CrossRef]

Mann, R. H. K. (1980) The growth and reproductive strategy of the gudgeon, Gobio gobio (L.), in two hard-water rivers in Southern England. Journal of Fish Biology, 17, 163-176. [CrossRef]

Mejri, R., Lo Brutto, S., Hassine, N., Arculeo, M., \& Ben Hassine, O. K. (2012). Overlapping patterns of morphometric and genetic differentiation in the Mediterranean goby Pomatoschistus tortonesei Miller, 1968 (Perciformes, Gobiidae) in Tunisian lagoons. Zoology, 115, 239-244. [CrossRef]

Monteiro, P., Bentes, L., Coelho, R., Correia, C., Erzini, K., Lino, P. G., ... Goncalves, J. M. S. (2010). Age and growth, mortality and reproduction of the striped sea bream, Lithognathus mormyrus Linnaeus 1758, from the south coast of Portugal (Algarve). Marine Biology Research, 6, 53-65. [CrossRef]

Morbey, Y. E. (2018). Female-biased dimorphism in size and age at maturity is reduced at higher latitudes in lake whitefish Coregonus clupeaformis. Journal of Fish Biology, 93, 40-46. [CrossRef]

Palma, J., \& Andrade, J. P. (2002). Morphological study of Diplodus sargus, Diplodus puntazzo and Lithognathus mormyrus (Sparidae) in the Eastern Atlantic and Mediterranean Sea. Fisheries Research, 57, 1-8. [CrossRef]

Pauly, D. (1984). Fish population dynamics in tropical waters: A manual for use with programmable calculators. ICLARM Studies and Reviews, 8, 1-325. ISBN 9711022044

Pervin, S. (2007). Embryological development of sharpsnout seabream (Diplodus puntazzo) eggs and the early period (lecithotrophic phase) larval morphogenesis. (Master dissertation). Retrieved from Council of Higher Education Thesis Center. (No 222942).

Reis, i., \& Ateş, C. (2020). Age, growth, length-weight relation, and reproduction of sand steenbras, Lithognathus mormyrus (Actinopterygii: Perciformes: Sparidae), in the Köyceğiz Lagoon, Mediterranean. Acta Ichthyologica et Piscatoria, 50, 445-451. [CrossRef]
Ricker, W. A. (1975). Computation and interpretation of biological statistics of fish populations. Journal of the Fisheries Research Board of Canada, 191, 1-382. ISBN 1932846239

Russel, B., Carpenter, K. E., Pollard, D., Mann, B. Q., \& Buxton, C. D. (2014). Lithognathus mormyrus. The IUCN Red List of Threatened Species 2014. IUCN. https://doi.org/10.2305/IUCN.UK.2014-3

Satılmış, H. H., Sümer, Ç., Aksu, H., \& Çelik, S. (2014). About the new record of striped seabream Lithognathus mormyrus L., 1758) (Pisces: Teleostei: Sparidae) from the coastal water of the Southern Black Sea, Turkey. Journal of Animal and Veterinary Advances, 13, 171-173. https://doi.org/10.36478/javaa.2014.171.173

Schaefer, K. M., (1989). Morphometric analysis of Yellowfin tuna Thunnus albacares from the Pacific Ocean. Inter-American Tropical Tuna Commission, 19, 389-427.

Silva, A. (2003). Morphometric variation among sardine (Sardina pilchardus) populations from the northeastern Atlantic and the western Mediterranean. ICES Journal of Marine Science, 60, 1352-1360. [CrossRef]

Sümer, Ç., Özdemir, G., \& Ertekin, H. (2014). Age, growth and reproduction of the striped seabream, Lithognathus mormyrus (Pisces: Sparidae), in the Beymelek Lagoon (southwestern coast of Turkey). Cahiers de Biologie Marine, 55, 37-42. https://doi.org/10.21411/CBM.A.D2639BEA

Turan, C. (1999) A note on the examination of morphometric differentiation among fish populations: the truss system. Turkish Journal of Zoology, 23, 259-263.

Turan, C. (2004). Stock identification of Mediterranean horse mackerel (Trachurus mediterraneus) using morphometric and meristic characters. ICES Journal of Marine Science, 61, 774-781. [CrossRef]

Turkish Statistical Institute, 2019. Fisheries statistics. Turkish Statistical Institute. https://biruni.tuik.gov.tr/medas/?kn=97\&locale=tr

Türkmen, M. \& Akyurt, I. (2003). Growth Characteristics, Sex Inversion and Mortality Rates of Striped Sea Bream, Lithognathus mormyrus L., in iskenderun Bay. Turkish Journal of Zoology, 27, 323-329.

Yankova, M. (2016). Alien invasive fish species in Bulgarian waters: An overview. International Journal of Fisheries and Aquatic Studies, 4, 282-290. 